\title{
Diagnostic Challenge in a Patient with Prosthetic Mitral Valve: Surgical Remnant or Artifact
}

\author{
Murat Gul, Sinan İnci \\ Department of Cardiology, Aksaray University, Aksaray, Turkey
}

\section{ARTICLE INFO}

Article history:

Submitted: 15. 7. 2020

Revised: 10. 10. 2020

Accepted: 17. 10. 2020

Available online: 29. 1. 2021

\section{Klíčová slova:}

Náhrada mitrální chlopně

Umělé šlašinky

\section{SOUHRN}

Incidentální echokardiografické nálezy u asymptomatických pacientů mohou při rozhodování v klinické praxi představovat problém. Regurgitace mitrální chlopně je častou srdeční vadou a hlavní príčinou rozvoje městnavého srdečního selhání a úmrtí. Přes řadu možností léčby se v případě vhodných anatomických poměrů dává přednost plastice mitrální chlopně. Transapikální metoda plastiky mitrální chlopně s implantací umělých šlašinek představuje novou a minimálně invazivní metodu pro pacienty s degenerativním postižením mitrální chlopně. Je prokázáno, že tento výkon je bezpečný, účinný a má vynikající dlouhodobé výsledky. I když se tato metoda při plastice srdeční chlopně používá často, v prýípadě mitrální chlopně se tento výkon provádí vzácně. V tomto článku popisujeme př́pad asymptomatického pacienta s kombinací plastiky mitrální a trikuspidální chlopně s použitím umělých šlašinek.

(c) 2021, ČKS
Keywords:

Neochordae

Prosthetic mitral valve ring mitral valve repair leads to many advantages, such as better left ventricular volume and contractility in the future. ${ }^{5}$ Herein, we present an asymptomatic patient with a combination of mitral and tricuspid valve prostheses with artificial neochordae. Mitral regurgitation (MR) is a common valvular heart disease, which is the cause of congestive heart failure and death. The estimated prevalence was $2 \%$ in the general population and $7 \%$ in those older than 75 years of age. ${ }^{1}$ Although primary MR is considered a structural disease of mitral valve apparatus, functional or secondary MR mainly results from left ventricular dilatation. There are a variety of treatment options, and mitral valve repair remains the preferred treatment when the anatomy is suitable. Mitral valve repair with neochordae implantation is a novel and minimally invasive technique in patients with degenerative mitral valve disease. ${ }^{2}$ It has been shown that this procedure seems safe and effective with excellent long-term results. ${ }^{3,4}$ Preserving at least some mitral chordae (CT) du-

\section{The case}

A 74-year-old asymptomatic male with a history of hypertension and diabetes mellitus admitted to our hospital for routine control. Elective coronary angiography was performed because of severe symptomatic MR and moderate tricuspid regurgitation 13 months ago. Subsequently, mitral and tricuspid valve replaced by a mechanical prosthesis and coronary artery bypass grafting were performed concomitantly. Blood pressure was $125 / 70 \mathrm{mmHg}$ and heart rate was $62 \mathrm{bpm}$ in physical examination. Electrocar- 


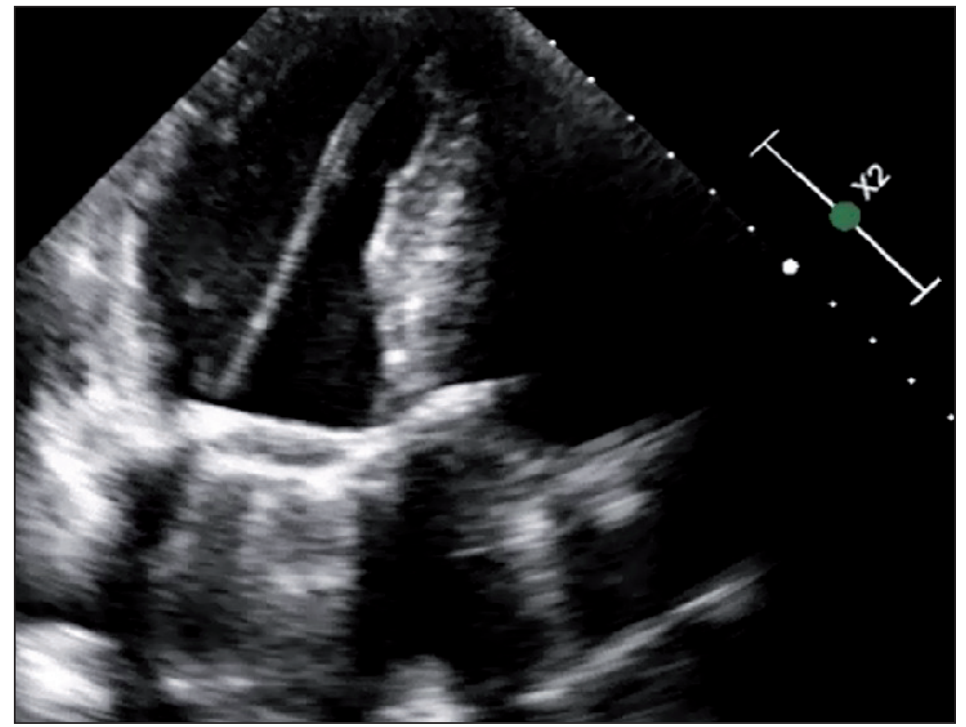

Fig. 1 - Two linear echo bright densities from posterior mitral annulus to left ventricular apex.

diogram showed normal sinus rhythm. Blood tests were unremarkable with an international normalized ratio (INR) of 3.1. Transthoracic echocardiography (Epiq 7 with X5-1 matrix probe; Philips Medical Systems, Andover, MA) demonstrated that there were left ventricular ejection fraction of $61 \%$ and functional mitral and tricuspid valve prosthesis. Mean valve gradients were $7 \mathrm{mmHg}$ and 6 $\mathrm{mmHg}$, respectively. The apical four-chamber view revealed a remarkable two linear echo bright densities from posterior mitral annulus to left ventricular apex (Fig. 1). Color Doppler imaging revealed blood flow in both sides of an artificial image. However, when repositioning the transthoracic probe to a more apicolateral position, a chordae was noticed that extended from mitral annulus to apex. Therefore, the apparent image was identified as an artificial neochordae. Eventually, the patient was discharged without additional therapy.

\section{Discussion}

Mitral valvular apparatus is a dynamic and complex structure that consists of leaflets, CT, and the papillary muscles. The primary function of the $C T$ is to transmit the contraction and relaxation of the papillary muscles during the cardiac cycle, ensuring effective valvular coaptation. Also, CT contributes significantly to preserving the ventricular structure and maintenance of cardiac output. ${ }^{6}$

There has long been controversy regarding the complete removal or preservation of the natural mitral chordae in mitral valve surgery. Recent evidence suggests that at least some CT protection may have many advantages, such as reducing posterior left ventricular disruption, left ventricular dilatation, and improving contractility. ${ }^{7,8}$ This can be explained by the fact that the mitral valve is directly a part of the left ventricular contractile apparatus, and plays a substantial role in cardiac output. Unfortunately, partial or total chordal excision may be necessary to adequately debulk the mitral valve tissue, and allow proper seating of the prosthesis. In the case of total chordal excision, alternative techniques have been proposed, such as reconstructing with synthetic chordae replacement.

Replacement of neochordae made from polytetrafluoroethylene (PTFE) is a widely used method in mitral valve repair due to elongated or ruptured mitral chordae. ${ }^{9}$ This technique has become a conventional approach to correct the mitral regurgitation that provides excellent results and durability in the long term. ${ }^{9}$ Posterior leaflet prolapse is the most common pathology, causing severe $M R$, and has a higher success of durable repair than anterior leaflet disease or severe bileaflet disease. ${ }^{10}$ Potential advantages of neochords are the preservation of a large coaptation surface and preservation of leaflet mobility. ${ }^{11}$ Preservation of anatomic continuity between mitral annulus and papillary muscles results in improving left ventricular systolic function after mitral valve repair. Major limitation of this technique is the absence of combined treatment of annular dilatation and mitral regurgitation. ${ }^{12}$ Coexistence of prosthetic valve and artificial chordae is very rare in the literature. In our case, distal tip of the artificial chordae was fixed to the apex instead of the papillary muscle unlike standard surgery. We thought that the surgeon aimed to reduce posterior left ventricular wall disruption with implanting artificial posterior chordae during valve replacement. Because we know that posterior CT reduces the longitudinal tension on the left ventricular posterior free wall and improves function.

In conclusion, cardiologists should be aware of mitral valve prosthesis and artificial neochordae coexistence in order to avoid misdiagnosis and unnecessary diagnostic procedures.

\section{Conflict of interest}

The authors report no financial relationships or conflicts of interest regarding the content herein.

\section{Funding body}

None. 


\section{Informed consent}

The informed and signed consent was obtained from the patient.

\section{References}

1. Baumgartner H, Falk V, Bax JJ, et al. 2017 ESC/EACTS Guidelines for the management of valvular heart disease. Eur Heart J 2017;38:2739-2791.

2. Caballero A, Mao W, McKay R, Sun W. Transapical mitral valve repair with neochordae implantation: FSI analysis of neochordae number and complexity of leaflet prolapse. Int J Numerical Methods Biomed Eng 2020;36:e3297.

3. David TE, Armstrong S, Ivanov J. Chordal replacement with polytetrafluoroethylene sutures for mitral valve repair: a 25 year experience. J Thorac Cardiovasc Surg 2013;145:1563-1569.

4. Colli A, Manzan E, Aidietis A, et al. An early European experience with transapical off-pump mitral valve repair with NeoChord implantation. Eur J Cardiothorac Surg 2018;54:460 466.

5. Zakai SB, Khan SU, Rabbi F, Tasneem H. Effects of mitral valve replacement with and without chordal preservation on cardiac function: early and mid-term results J Ayub Med Coll Abbottabad 2010;22:91-96.
6. Ross CJ, Hsu MC, Baumwart R, et al. Quantification of LoadDependent Changes in the Collagen Fiber Architecture for Strut Chordae Tendineae - Leaflet Insertion of Porcine Atrioventricular Heart Valves. Biomech Model Mechanobiol 2020 Aug 18. doi: 10.1007/s10237-020-01379-4. Epub ahead of print. PMID: 32809131

7. Spencer FC, Galloway AC, Colvin SB. A clinical evaluation of the hypothesis that rupture of the left ventricle following mitral valve replacement can be prevented by preservation of the chordae of the mural leaflet. Ann Surg 1985;202:673-680.

8. Moon MR, DeAnda Jr A, Daughters GT II, et al. Experimental evaluation of different chordal preservation methods during mitral valve replacement. Ann Thorac Surg 1994;58:931-944.

9. Gillinov AM, Cosgrove DM, Blackstone $E H$, et al. Durability of mitral valve repair for degenerative disease. J Thorac Cardiovasc Surg 1998;116:734-743.

10. Suri RM, Clavel MA, Schaff HV, et al. Effect of recurrent mitral regurgitation following degenerative mitral valve repair: long-term analysis of competing outcomes. J Am Coll Cardiol 2016;67:488-498.

11. Lange R, Guenther T, Noebauer C, et al. Chordal replacement versus quadrangular resection for repair of isolated posterior mitral leaflet prolapse. Ann Thorac Surg 2010;89:1163-1170.

12. Savic V, Pozzoli A, Gulmez G, et al. Transcatheter mitral valve chord repair. Ann Cardiothorac Surg 2018;7:731-740. 